\title{
Pengembangan Instrumen Tes Kemampuan Berpikir Kreatif Berbasis Pendekatan Konflik Kognitif
}

\author{
Rangga Alif Faresta ${ }^{1 *}$, Walid Anggara ${ }^{1}$, Tegar Agusfian Mandiri ${ }^{1}$, Adi Septiawan ${ }^{2}$ \\ ${ }^{1}$ Pendidikan Fisika, FKIP, Universitas Mataram, Lombok, Indonesia. \\ ${ }^{2}$ Manajemen, Fakultas Ekonomi dan Bisnis, Universitas Maaram, Lombok, Indonesia.
}

DOI: https://doi.org/10.29303/goescienceedu.v1i2.55

\section{Article Info}

Received : 2 Agustus 2020

Revised : 20 November 2020

Accepted: 22 Desember 2020

\begin{abstract}
Abstrak: Kemampuan berpikir kreatif merupakan bagian dari ranah afektif yang juga menentukan keberhasilan pembelajaran. Peneliti bermaksud melakukan penelitian pengembangan untuk menghasilkan instrumen kemampuan berpikir kreatif yang layak. Sehingga dapat digunakan sebagai instrumen penilaian kemampuan berpikir kreatif pada peserta didik. Penelitian ini merupakan peneltian pengembangan atau Research and Development (R\&D) dengan model 4D yaitu Define, Design, Develop dan Disseminate. Pada penelitian ini, hanya dilakukan sampai tahap develop, yaitu validasi ahli dan validasi praktisi Instrumen yang dikembangkan berupa soal uraian. Sampel yang digunakan adalah peserta didik SMA kelas X. Berdasarkan penilaian validator ahli, soal kemampuan berpikir kreatif memiliki kelayakan dari rata-rata seluruh aspek sebesar 3,25 dengan kategori sangat baik dan nilai validasi isi sebesar 0,71 dengan kategori valid. Sedangkan penilaian dari validator praktisi, diperoleh kelayakan dari nilai rata-rata seluruh aspek sebesar 3,71 dengan kategori sangat baik dan validasi isi sebesar 0,89 dengan kategori valid. Sehingga dapat disimpulkan jika instrumen penilaian kemampuan berpikir kreatif layak digunakan untuk mengukur tingkat berpikir kreatif peserta didik.
\end{abstract}

Kata Kunci: Kemampuan berpikir kreatif; penelitian pengembangan; Pendekatan konflik kognitif

Abstract: The ability to think creatively is part of the affective domain that also determines the success of learning. The researcher intends to conduct developmental research to produce a viable creative thinking tool. So that it can be used as a tool to assess students' creative thinking ability. This research is a development research or Research and Development (R\&D) with the 4D model, namely Define, Design, Develop and Disseminate. In this study, it was only performed up to the development phase, namely expert validation and practitioner validation. The tools developed were descriptive questions. The sample used were class $X$ high school students. Based on the expert validator's rating, the demand for creative thinking averaged 3.25 in all aspects with a very good category and a content validation value of 0.71 in the valid category. Meanwhile, the practitioner validator rating achieved the feasibility of the mean value of all aspects of 3.71 with the very good category and the content validation of 0.89 with the valid category. Thus, it can be concluded that the creative thinking assessment tool is suitable to be used to measure students' creative thinking level.

Keywords: Creative thinking skills; development research; Cognitive conflict approach

\section{Pendahuluan}

Menurut Aji (2017) dalam menghadapi tantangan abad ke-21, guru harus mempersiapkan peserta didik menjadi seorang penyelidik, pemecah masalah, dan berpikiran kreatif. Tantangan abad 21 membuat guru harus mampu menciptakan metode pembelajaran yang dapat mengembangkan 
keterampilan agar bisa memperkuat modal sosial (social capital) dan modal intelektual (intellectual capital), yang disingkat dengan 4C: communication, collaboration, critical thinking and problem solving, dan creativity and innovation. Sejalan dengan penelitian Zubaidah (2016) yang menyatakan bahwa standar baru diperlukan agar peserta didik kelak memiliki kompetensi yang diperlukan pada abad ke-21. Sekolah ditantang menemukan cara agar peserta didik suskses dalam pekerjaan dan kehidupan melalui penguasaan keterampilan berpikir kreatif, pemecahan masalah yang fleksibel, berkolaborasi dan berinovasi. Untuk itu, lingkungan belajar harus dapat memfasilitasi pengembangan keterampilan abad 21.

Salah satu keterampilan yang harus dikuasai oleh peserta didik adalah kemampuan berpikir kreatif. Rawat et al (dalam Gunawan, 2017) mengungkapkan bahwa kemampuan berpikir kreatif adalah salah satu tujuan utama seluruh pendidikan di dunia. Seseorang yang memiliki kemampuan berpikir kreatif dapat menghadapi dan menyelesaikan suatu persoalan dengan tindakan yang tepat di luar dari kebiasaan yang dilakukan. Kemampuan berpikir kreatif melahirkan sesuatu yang baru, baik berupa gagasan maupun karya nyata yang relatif berbeda dengan yang telah ada sebelumnya. Sesuatu yang baru tidak harus berupa hasil atau ciptaan yang benar-benar baru, tetapi dapat berupa hasil penggabungan dua atau lebih konsep yang sudah ada (Munandar, 2009). Pendapat lain dari Armandita (2017) mengatakan bahwa kemampuan berpikir kreatif merupakan hasil interaksi antara peserta didik, pendidik serta lingkungannya. Berpikir kreatif identik dengan mengungkapkan suatu gagasan baru. Dalam pengertian ini gagasan yang dituangkan berdasarkan akal pemikiran sehat dan logis serta tidak menyinggung ataupun menyalahkan gagasan orang lain.

Namun, fakta dilapangan menunjukan suatu perbedaan. Berdasarkan observasi dan wawancara dengan peserta didik dan guru di MAN 2 Mataram,.menunjukan jika hasil belajar fisika rendah. Tentu, ini mengindikasikan kemampuan berpikir yang dimiliki oleh peserta didik juga rendah.

Tabel 1. Hasil Nilai Mid Semester MAN 2 Mataram

\begin{tabular}{lll}
\hline Kelas & Nilai Rata-Rata & KKM \\
\hline X MIA 1 & 51 & 75 \\
X MIA 2 & 54 & 75 \\
X MIA 3 & 51 & 75 \\
\hline
\end{tabular}

Dari tabel tersebut dapat terlihat jika nilai ratarata peserta didik masih berada di bawah KKM. Adanya kesalahan konsep yang tinggi juga menjadi salah satu factor yang menyebabkan kemampuan berpikir kreatif sulit untuk ditingkatkan. Semakin baik konsep yang dimiliki peserta didik, maka semakin mudah dalam memunculkan gagasan baru dan mengembangkan kemampuan berpikir kreatif. Begitu juga sebaliknya, semakin rendah konsep yang dimiliki peserta didik, maka semakin sulit dalam memunculkan gagasan baru yang akan berpengaruh pada kemampuan berpikir peserta didik. Berdasarkan penelitian Nisrina et al (2016), semakin kurang mampu peserta didik memahami dan menguasai konsep terutama pada mata pelajaran fisika, maka gagasan baru akan sulit timbul pada diri mereka.

Tentu guru harus bisa mengidentifikasi kemampuan berpikir dari setiap individu melalui sutu alat ukur yang valid dan reliabel. Berdasarkan permasalahan di atas, maka peneliti bermaksud untuk mengembangkan suatu instrumen tes untuk mengukur tingkat kemampuan berpikir peserta didik. Sehingga guru dapat melakukan startegi dan pendekatan Instrumen tes yang dikembangkan diintegrasikan dengan suatu pendekatan yang dapat meminimalisir kesalahan konsep, yaitu pendekatan konflik kognitif. Baser (2006) \& Sirait (2012) menyatakan bahwa konflik kognitif dapat meningkatkan penguasaan konsep fisika peserta didik lebih signifikan dibandingkan dengan model konvensional.

\section{Metode}

Metode yang digunakan dalam penelitian ini adalah Research and Development (R\&D) dengan model 4D yaitu define, design, develop dan disseminate (Sugiyono, 2009).

a. Tahap Define (pendefinisian)

Pada tahap ini dilakukan identifikasi masalah pada pembelajaran yang berlangsung di kelas. Sehingga dapat ditentukan isi dari instrumen tes ang dikembangkan

b. Tahap Design (perancanga)

Dalam tahap ini dilakukan pemilihan edia untuk merancang draft instrumen tes kemampan berpikir kreatif. Dilakukan juga perancangan materi yang disesuaikan dengan kurikulum 2013.

c. Tahap Develop (pengembangan)

Tujuan dalam tahap ini adalah menghasilkan instrumen tes yang telah divalidasi dan telah mendapatkan saran dari validator ahli dan validator praktisi. Selanjutnya dilakukan perbaikan pada soal kemampuan berpikir kreatif sesuai saran valdator.

d. Tahap Disseminate (penyebaran)

Tujuan tahap ini untuk menyebarluaskan produk berupa modul pembelajaran fisika berbasis pendekatan konflik kognitif yang telah dikembangkan setelah uji coba terbatas. Namun pada penelitian ini, tahap Diseeminate tidak dilakukan. 
Instrumen penelitian berupa lembar validasi untuk soal kemampuan berpikir kreatif. Analisis kelayakan modul menggunakan SBi (simpangan baku ideal) dengan tahapan:

a. Menghitung rata-rata skor aspek penilaian

$\bar{X}=\frac{\sum x}{n}$

Dimana:

$\bar{X}=$ skor rata-rata

$\sum x=$ jumlah skor

$n=$ jumlah penilai

b. Mengkonversikan Skor menjadi Skala 4

Acuan perubahan skor menjadi skala 4 adalah dengan menghitung rata-rata ideal (Mi) yang dapat dicari dengan persamaan

$M i=\frac{1}{2}($ skor maksimum ideal + skor minimum ideal $)$

Setelah mendapatkan nilai $M i$, selanjutnya mencari simpangan bauku ideal (SBi) dengan persamaan

$S B i=\frac{1}{6}($ skor maksimum ideal - skor minumum ideal $)$

c. Menentukan Kriteria Penilaian

Kritersia penilaian berdasarkan simpangan baku yang telah dihitung dengan menggunakan rumus diatas dapat dilihat pada tabel 2 .

Tabel 2. Rentang Skor Kuantitatif

\begin{tabular}{ll}
\hline Rentang Skor Kuantitatif & Kategori \\
\hline$X \geq M i+1,5 S B i$ & Sangat Baik \\
$M i+1,5 S B i \geq X \geq M i$ & Baik \\
$X>M \geq M i-1,5 S B i$ & Kurang Baik \\
$M i-1,5 S B i>X$ & Tidak Baik \\
\hline
\end{tabular}

(Mardapi, 2012)

Persamaan kriteria penilaian tersebut kemudian diubah dalam rentang skala 1- 4

$\operatorname{Mi}($ Mean Ideal $)=\frac{1}{2}(4+1)=2,5$

SBi (Simpangan Baku Ideal) $=\frac{1}{6}(4-1)=0,5$

Berdasarkan kriteria penilaian skala nilai 4 maka diperoleh kriteria penilaian untuk penelitian yaitu pada Tabel 3 berikut.

\begin{tabular}{ll}
\hline Rentang Skor Kuantitatif & Kategori \\
\hline$X \geq 3,25$ & Sangat Baik \\
$3,25 \geq X \geq 2,5$ & Baik \\
$2,5>X \geq 1,75$ & Kurang Baik \\
$1,75>X$ & Tidak Baik \\
\hline
\end{tabular}

(Mardapi, 2012)

Dan untuk uji validasi menggunakan uji statistik Aiken's $V$. Analisis validitas penelitian ini menggunakan koefisien validitas yang dikembangkan oleh Aiken's V (Azwar, 2015) dengan rumus:

$V=\frac{\Sigma s}{n(c-1)}$

Keterangan :

$l_{0}=$ angka penilaian validitas terendah

$c=$ angka penilaian validitas tertinggi

$r=$ angka yang diberikan oleh validator

$n=$ jumlah validator

Jika nilai koefisien validitas Aiken berkisar antara 0-1, maka dianggap sudah memiliki nilai validitas yang memadai (Hendryadi, 2017).

\section{Hasil Dan Pembahasan}

Pada tahap define (pendefinisian) didapatkan hasil jika adanya indikasi kemampuan berpikir kreatif yang dimiliki oleh peserta didik rendah. Ini terlihat dari rata-rata hasil mid semester yang masih berada di bawah KKM. Dari hasil identifiasi awal inilah kemudian dikembangkan suatu instrumen tes kemampuan berpikir kreatif. Selanjutanya pada tahap design (perancangan) dihasilkan suatu draft soal kemampuan berpikir kreatif berdasarkan indikator yang dikemukakan oleh Munandar (2012), yaitu flexibility, fluently, elaboration dan original. Dimana materi yang dipilih adalah materi usaha dan energi berdasarkan kurikulum 2013.

Setelah draft dihasilkan maka selanjutnya dilakukan validasi dan analisis kelayakan insrumen tes oleh 3 orang dosen sebagai validator ahli dan 3 orang guru sebagai validator praktisi. Hasil dari penilaian validator ahli dan validator praktisi berupa skor kuantitatif.

Tabel 3. Hasil Analisis Kelayakan Soal Kemampuan Berpikir Kreatif

\begin{tabular}{lllll}
\hline \multirow{2}{*}{ Aspek yang dinilai } & \multicolumn{2}{c}{ Validator Ahli } & \multicolumn{2}{c}{ Validator Praktisi } \\
\cline { 2 - 5 } & $\overline{\boldsymbol{X}_{\text {per }} \text { aspek }}$ & Kategori & $\overline{\boldsymbol{X}}$ per aspek & Kategori \\
\hline Isi & 3,00 & Baik & 3,60 & Sangat Baik \\
Kebahasaan & 3,08 & Baik & 3,67 & Sangat Baik \\
Penyajian & 3,33 & Sangat Baik & 3,83 & Sangat Baik \\
Kontruksi & 3,58 & Sangat Baik & 3,75 & Sangat Baik \\
Rata-rata seluruh aspek & $\mathbf{3 , 2 5}$ & Sangat Baik & $\mathbf{3 , 7 1}$ & Sangat Baik \\
\hline
\end{tabular}


Tabel 4. Hasil Analisis Validasi Soal Kemampuan Berpikir Kreatif

\begin{tabular}{lllll}
\hline \multirow{2}{*}{ Aspek yang dinilai } & Validator Ahli & & Validator Praktisi & \\
\cline { 2 - 5 } & Nilai $\boldsymbol{V}$ per aspek & Kategori & Nilai $\boldsymbol{V}$ per aspek & Kategori \\
\hline Isi & 0,64 & Tidak Valid & 0,87 & Valid \\
Bahasa & 0,67 & Tidak Valid & 0,89 & Valid \\
Kegrafisan & 0,72 & Valid & 0,94 & Valid \\
Konstruksi & 0,83 & Valid & 0,91 & Valid \\
Jumlah & 11,36 & Valid & 14,3 & Valid \\
Nilai $V$ rata-rata & 0,71 & $\mathbf{0 , 8 9}$ & \\
\hline
\end{tabular}

Dapat dilihat pada tabel 3, aspek yang dinilai meliputi aspek isi, kebahasaan, penyajian dan konstruksi. Dari penilian validator ahli memperoleh rata-rata seluruh aspek sebesar 3,25 sehingga memperoleh kategori sangat baik. Begitu juga dengan penilian yang dilakukan oleh validator praktisi, dimana seluruh aspek memperleh nilai rata-rata sebesar 3,71 sehingga memperoleh kategori sangat baik. Sehingga dapat dsimpulkan baik dari penilaian validator ahli dan validator praktisi, soal kemampuan berpikir kreatif mendapatkna kategori sangat baik.

Untuk hasil analisis validasi soal kemampuan berpikir kreatif, juga memiliki aspek penilaian yang sama dengan analisis kelayakan yaitu aspek isi, kebahasaan, penyajian dan konstruksi. Dari penilaian validator ahli, diperoleh nilai rata-rata $V$ sebesar 0,71 dan dari penilaian validator praktisi diperoleh nilai rata-rata $V$ sebesar 0,89 . Sehingga mendapatkan kategori valid.

Berdasarkan penilaian validator ahli dan validator praktisi, soal kemampuan berpikir kreatif layak dan valid untuk digunakan mengukur tingkat kemampuan berpikir kreatif peserta didik.

\section{Kesimpulan}

Berdasarkan pembahasan dapat disimpulkan jika produk yang dikembangkan berupa soal kemampuan berpikir kreatif dapat digunakan pada pembelajaran untuk mengukur kemampuan berpikir kreatif peserta didik.

\section{Daftar Pustaka}

Aji, D.S. (2017). Pengembangan Modul Pembelajaran Fisika Berbasis Problem Based Learning untuk Meningkatkan Kemampuan Pemecahan Masalah Fisika.Science Education Journal, 1 (1), 36-51.

Armandita, P., Wijayanto, E., Rofiatus, L., \& Susanti, A. (2017). Analisis Kemampuan Berpikir Kreatif Pembelajaran Fisika Di Kelas XI MIA 3 Sma Negeri 11 Kota Jambi. Jurnal Penelitian Ilmu Pendidikan, 10(2), 130-135.
Azwar, S. (2012). Reliabilitas dan Validitas. Yogyakarta: Pustaka Pelajar

Baser, M. (2006). Fostering conceptual change by cognitive conflict based instruction on students' understanding of heat and temperature concepts. Eurasia Journal of Mathematics, Science and Technology Education, 2(2).

Gunawan. (2017). Keterampilan Berpikir dalam Pembelajaran Sains. Mataram: Agra Puji Press.

Hendryadi. (2017). Validitas Isi: Tahap Awal Pengembangan Kuesioner. Jurnal Riset Manajemen dan Bisnis (JRMB) Fakultas Ekonomi UNIAT 2(2).

Mardapi, D. (2012). Pengukuran Penilaian \& Evaluasi Pendidikan. Yogyakarta: Nuha Medika.

Munandar, U. (2009). Pengembangan Kreativitas Anak Berbakat. Jakarta: PT. Rineka Cipta

Nisrina, N., Gunawan, G. \& Harjono, A. (2017). Pembelajaran Kooperatif dengan Media Virtual untuk Peningkatan Penguasaan Konsep Fluida Statis Siswa. Jurnal Pendidikan Fisika dan Teknologi, 2(2), 66-72.

Sirait, J. (2012). Pendekatan Pembelajaran Konflik Kognitif Untuk Meningkatkan Penguasaan Konsep Siswa SMA Pada Topik Suhu dan Kalor. Jurnal PMIPA, 1(2).

Sugiyono. (2009). Metode Penelitian Pendidikan: Pendekatan Kuantitatif, Kualitatif, Dan RED. Bandung: Alfabeta.

Zubaidah, S. (2016). Keterampilan Abad ke 21: Keterampilan yang Diajarkan melalui Pembelajaran. Ini Disampaikan pada Seminar Nasional Pendidikan dengan Tema "Isu-isu Strategis Pembelajaran MIPA Abad XXI, 21(1). 